\title{
Factors influencing banking employee satisfaction in Saudi
} \section{Arabia}

\author{
Alaa Brahim Alqarawi (Student) \\ MSc in Accounting, Department of Accounting \\ College of Business and Economics, Qassim University \\ Reef Mohammad AlSheail (Student) \\ MSc in Accounting, Department of Accounting \\ College of Business and Economics, Qassim University
}

\begin{abstract}
The main purpose of this research was to find out the factors that influenced employee's satisfaction in order to enhance the employee's functional commitment to employment and productivity. The study was based on primary data collected from banking industry in Saudi Arabia. A structured closed ended questionnaire was distributed among the employees of the Bank. The questionnaire used Likert Scale to from 1 to 5 for the responses of the employees. From literature factors impacting employee satisfaction were selected, these factors were (motivation - education communication - trust - conflict - culture of the organization - human resources policies and practices). The analysis of the results of the questionnaire revealed that the incentives, education, organizational culture, human resource policies and practices have a positive impact on the job satisfaction of the Bank's employees. While in relation to the factor of trust, conflict and communication, their impact was negative on the level of job satisfaction.
\end{abstract}

Keyword: Job satisfaction, Organizational Behavior, Organizational Culture, Learning, Conflict, Communication.

\section{INTRODUCTION}

In today's more competitive, globalized, and fast-growing business area, business organizations are using a number of ways, methods, strategies and tactics in order to understand and analyze the factors that positively and negatively affect the employee behaviors in the workplace. In addition to this, it should also be noted down that, by analyzing and accessing such factors or forces, a company can overcome and deal with challenging and serious workplace issues that may negatively impact the overall success and growth of the company.

Employee satisfaction is a term that explains that employees are happy or not within the organization. An employee's overall satisfaction is the outcomes of job that defined in different factors. There are a number of individual and organizational aspects that make an employee satisfy at the workplace. In the workplace or organization, employee satisfaction is a motivational factor that encourages an individual employee to attain organizational long term and strategic goals and objectives in an effective and proper manner.

In addition to this, it should also be noted down that, in the present time, most of business firms or organizations focus on employee satisfaction in order to attain a number of financial and non-financial objectives. For case, a company adopts effective measures and ways to make their employees more satisfy so that it can improve organizational productivity ad revenue. Employee satisfaction is one of the important factors in the total success of the business firm 
base it has a direct impact on the customer satisfaction level. If the employees are happy and satisfy with their job, they would handle the issues of the customers in a more innovative and dynamic manner.

Furthermore, it is also found that, satisfaction of employees is also important and valuable to the organizations directly or in directly. For case, by making employee satisfied, a company can improve their skills and abilities to do work more effectively. In the same way, they would be able to handle more pressure situations easily and effectively. In addition to this, in order to overcome absenteeism, increase loyalty, bring innovation, development and creativity, employee satisfaction is also essential and important for the organizations. So, it can be said that, the overall success and growth of a company depends on the satisfaction level of employees because employees are the most important and valuable assets of a company that help a company in making it successful in the market.

Moreover, in the current time, a number of techniques, approaches, ways, strategies and methods are used and applied by the business managers or leaders in order to motivate the employees and satisfy them. In the same way, it can be said that, there are several significant factors or forces that play a key role improving the job satisfaction or employee satisfaction. The level of employee satisfaction is observed and monitored by the managers or leaders by employee's positive feeling, attitude and perception towards their job, functions, and responsibilities within the company.

\section{RELATED CONCEPTS}

Organization Behaviour: Organizational behaviour is the significant way by which people of a company interact or communicate with each other in a group or within the organization in order to make more efficient organization (Lussier, 2011).

Employee Satisfaction: It is a motivational factor that makes employees' happy at the workplace.

Motivation: It can be defined as internal and external factor that stimulate desire and energy in an individual towards organizational goals or objectives (Şahin, 2012).

Learning: It is a systematic and innovative process of acquiring or modifying new and existing knowledge, ideas, behaviour, skills, values, preferences etc.

Biographical Characteristics: These are the Personal Characteristics about an individual personality, such as: age, gender, race, tenure.

Communication: It is a way to communicate or conveying the information on to another person (Latif, 2012).

Conflict: It can be defined as the disagreement or argument between two or more people or groups towards a particular thing or subject (Sadri and Bowen, 2011).

Trust: It can be defined as: reliability, truth, and fairness.

Organization Culture: Organizational culture is a system of shared assumptions, behaviours, values, and beliefs (Kraimer, Seibert, Wayne, Liden and Bravo, 2011). 
Human Resource Practices and Policies: These are the strategies, approaches, ways and methods used to manage the human resources in the workplace.

Organization Design: It can be defined as the formal organizational processes that play a key role in integrating people, information, technology and system within a company (Sharf, 2016).

\section{IMPORTANCE OF EMPLOYEE SATISFACTION TO THE ORGANIZATION}

In the organization, employee satisfaction brings creativity, innovation, new ideas, development, etc. Moreover, employee satisfaction has also helped a company in attaining its strategic, core and long-term objectives and vision (Khan, Khan, and Khan, 2011). Employee satisfaction within the organization positively and directly increases the employee's and organizational performance. It is because employee satisfaction and performance are the two critical factors that are correlated with each other. If an employee is satisfied with the outcomes of the job performance, it would motivate employees to perform their tasks and functions more effectively. Employee satisfaction is also important for the organizational commitment and dedication (Ely, Ibarra, and Kolb, 2011). Employee satisfaction and morale are related with each other because the employee satisfaction level increase moral standard of an individual employee. On the other hand, it is also found that, employee satisfaction is also playing a key role in reducing the employee absenteeism; developing a positive mental attitude, enhance customer satisfaction and organizational performance and success (Kraimer, Seibert, Wayne, Liden, and Bravo, 2011).

\section{IMPACT OF EMPLOYEE SATISFACTION IN THE ORGANIZATION}

Employee Satisfaction has a direct as well as indirect impact on the overall success, growth and performance of the organization and ensures high revenue, market share, profitability, and organizational reputation. Employee Satisfaction promotes innovation and ethical standards within the company or firm. It means, there is a direct and strong relationship and connection exits among the employee satisfaction and organizational performance. For example, more satisfied employee's plays key role in satisfying the customers of the business firms by solving their problems related to product/services (Karim, Huda, and Khan, 2012). In the same way, if the customer would be happy and satisfied, this would ultimately increase the revenue, market share, and profitability of the company directly or indirectly.

In addition to this, it is also important to know that, employee satisfaction is also affecting a company's reputation, and image in the market. Moreover, by satisfying employees, a company or firm can improve customer retention and overcome administrative and operational costs directly or indirectly. In addition to this, employee satisfaction also has a direct and positive impact on the employees' commitment towards the organization. This motivates and encourages an employee to work effectively to attain the long-term vision, and objectives of the company. In the same way, employee satisfaction is an important factor that plays key role in explaining organizational success, growth and performance (Khan, Khan and Khan, 2011)

By considering all these aspects, a company pays attention on developing, and creating effective ways, and strategies to enhance employee satisfaction, work performance and productivity. For case, several effective measures and practices are used by the company to enhance the morale of the employees so that the overall performance can be improved in an effective and proper manner and ultimately results in higher profits, customer satisfaction as well as customer retention. Employee satisfaction also has a major impact on the quality as well as the profitability level of the company. For instance, Service quality and customer satisfaction are the interrelated and connected with each other and allow a company to 
improve its revenue effectively and properly (Kraimer, Seibert, Wayne, Liden, and Bravo, 2011)

\section{REVIEW OF LITERATURE}

According to Alromaihi, Alshomaly, and George, (2017), there are a series of factors or elements that have a direct, positive and negative influence on employee satisfaction in the workplace. Moreover, there are several organizations, work environment, personal factors that directly influence the employee satisfaction level. For example, salaries \& wages, promotion opportunities, company policy, etc. are the most major organizational factor that affects an individual's employee satisfaction level (Schein. 1984).

In addition to this, it is found by Belbin, (2011), work group, working conditions, supervision, etc. are the environmental forces that influence employee satisfaction. On the other hand, age, seniority, tenure, personality, etc. are the key personal factors that have direct impact on the employee satisfaction level. Apart from this, Daley, (2012) explained that, communications; Trust, Motivation, Organization culture and Conflict etc. were the influencing factors that have both positive and negative impact on the employee performance and satisfaction level.

Johnson, Cowin, Wilson, and Young, (2012) explained that, communications is one of the major factor that have a direct impact on the employee satisfaction level. For example, the internal and external organizational communication plays key role in enhancing the employee engagement, improve skills \& knowledge and boost workplace productivity. Moreover, strategic internal communications system encourages and motivates the employees towards the goals and objective attainment and enhances employee satisfaction level. On the other hand, Kaur (2013) stated that, establishing some two-way communication systems within the company carry information from the top to the bottom and this overcome ambiguity of messages \& eliminate inaccuracies and enhance the satisfaction level of employees. In the same way, it can be said that, effective organizational culture improves the satisfaction level of employees within the company by reducing Confusion, Uncertainty, and developing Higher Morale.

In the words of Ismajli, Krasniqi, and Qosja, (2015), Trust is another most valuable factor that has both positive and negative impact on the employee satisfaction. For example, a company's trust on their employee make them happy, satisfy and motivated. So, it is important for the business firms to empower and encourage their employees to take strategic and best decisions for the overall success of the organization. This type of trust of a company on their employee improves worker productivity and improves the level of employee job satisfaction. Trust is a factor that has a direct impact on the employee satisfaction because trust affects the efficiency as well as the quality of the co-operation between organizational members. In the support of Brewster, and Mayrhofer, (2012) analyzed that; trust is essential and important in the business firms because it encourages positive employee relationships within the company and improves the work productivity of the employees. In the same way, it can be said that, employees would always prefer to work in organizations where they trust and feel trusted by the organization, because trust creates added value, improves the flow of information, and enhances relationships, interaction, and cooperation.

Hoekstra, (2011) found that, in the current time of globalization, organizations are facing a number of issues and challenges related to employee commitment, engagement, belief and retention of their employees. So, motivation is one of the factors that can overcome such issues and challenges in an effective and proper manner. It is because motivation provides guidance; 
resources, direction and rewards to the employees and thus improve employee satisfaction (Ely, Berra, and Kolb, 2011). There is a direct link between the motivation and job satisfaction so in order to improve the employee satisfaction, it is important for the companies to adopt a number of motivational tools, ways and strategies to improve the satisfaction level of employees in the workplace. Positive motivation improves an employee's job satisfaction, but the negative motivation reduces the level of job satisfaction (De Vos De Hauw and Van der Heijden, 2011).

Organization Culture: At the same time, Egan, (2013) stated that, an innovative and dynamic organization culture satisfies the basic human need of employees and motivates them towards organizational goals. For example, an innovative, positive and supportive organizational culture have a positive impact on the employee satisfaction and encourage them to attain a number of organizational goals and objectives in an effective and innovative manner. On the other hand, conflict is a factor that negatively affects the employee satisfaction level. For example, conflict among the team members minimizes the work performance and reduces the job satisfaction level directly or indirectly. Overall, it can be said that, there are a number of factors that influence employee satisfaction (Gurdjian, Halbeisen, and Lane, 2014).

\section{OBJECTIVE OF THE STUDY}

Given the emergence and increased interest in the term "job satisfaction" in the recent period, and the organizations have realized the importance of the satisfaction of their staff and the creation of an appropriate working environment for them to achieve their objectives. The organizations were interested in scientific research to identify the causes of dissatisfaction that the employees have and try to know their needs to try to achieve them. The objective of this study is to understand the factors influencing job satisfaction among Bank employees, to evaluate its causes, to understand the causes of job dissatisfaction in the case of its existence.

Also understanding the relationships between different variables and their impact on job satisfaction and determining the main factors affecting job satisfaction. Such as linking and understanding the relationship between incentives to employees and promotions at the bank and creating a comfortable working environment for employees to achieve a high satisfaction rate. The objectives of this study are to understand the nature of the bank's work and to reach conclusions through which recommendations are proposed by the two researchers to improve the level of job satisfaction in the bank to contribute to achieving its goals and strategies.

\section{METHODOLOGY}

This research is divided into two parts: the theoretical section, in which reference was made to the previous published researches and studies, and the latest information was obtained from scientific information and knowledge.

Following the research, ten previous literary studies were reviewed in this study, summarizing these studies and clarifying the main points. As for the practical section, it focuses on the design of a questionnaire to measure the level of job satisfaction for employees Banks. The questionnaire was distributed to employees. After receiving the results, they were analyzed, presented and explained.

The sample of the study consisted of the distribution of (135) questionnaires divided between males and females in all age groups and administrative levels. This questionnaire was analyzed. In this regard, important results have been reached in this subject, and on this basis, some recommendations have been made by the two researchers to the bank management to improve the bank's weaknesses and help the bank to reach a high rate of job satisfaction. 
Theoretical background was developed from previous researches, the researchers reviewed 15 previous studies and summarized the main findings and the most important findings.

\section{THE STUDY SAMPLE IN DETAIL}

The study was conducted in Qassim region of Saudi Arabia. The researchers collected data through questionnaire from 135 bank employees in males and females. The questionnaires were distributed in 14 female branches of banks and 23 male bank branches. It is to be noted that banks for males and females are separate in Saudi Arabia. The responses were collected from 91 male employees and 44 female employees.

The study was based on dependent and independent variables. Employee satisfaction was the dependent factor and the factors influencing the satisfaction were considered as independent variables which were further divided into three categories such as Individual level, group level, and Organizational level. At individual level the studied variables were motivation, learning, and biographical characteristics. At Group level the variables were Communication, trust, and conflict. At the organizational level the researchers investigated the influence of Organizational culture and Human Resource practices and policies on employee satisfaction.

\section{RESULTS, DISCUSSIONS AND CONCLUSIONS}

About the Respondents: Table 1 below presents a brief demographic profile of the respondents along the factors gender, age, education, marital status and salary per month. The results show that the respondents were mainly males $67.4 \%$ and females only $32.6 \%$. The majority of respondents were between the age group of 26 to 35 years (69.9\%), only 3.4\% were 20 to 25 years and $26.7 \%$ were above 35 years of age. The result showed that $50.4 \%$ of the respondents were bachelor degree holders and majority of the respondents were married $74.8 \%$. Regarding average of salaries, results showed that percentage of employees whose salaries are less than 5000 is $4.4 \%$, employees whose salaries are between 5000 to 1000 thousand is $71.9 \%$, and employees whose salaries are more than 10 thousand is $23.7 \%$.

Table-1; Respondents Demographic Analysis

\begin{tabular}{|l|l|}
\hline Gender & Percentage \\
\hline Male & $67.4 \%$ \\
\hline Female & $32.6 \%$ \\
\hline Age & \\
\hline 20 to 25 & $3.4 \%$ \\
\hline 26 to 35 & $69.9 \%$ \\
\hline More than 35 & $26.7 \%$ \\
\hline Education & \\
\hline Secondary & $8.9 \%$ \\
\hline Diploma & $37.8 \%$ \\
\hline Bachelor & $50.4 \%$ \\
\hline Master and PhD & $2.9 \%$ \\
\hline Marital Status & \\
\hline Single & $24.4 \%$ \\
\hline Married & $74.8 \%$ \\
\hline Divorced/Widow/Widower & $0.8 \%$ \\
\hline Salary per Month & \\
\hline Less than SAR 5000 & \\
\hline SAR 5000 to SAR 10000 & $71.9 \%$ \\
\hline More than SAR 10000 & $23.7 \%$ \\
\hline
\end{tabular}

Results on Employee Satisfaction: Table 2 and 3 presents the level of employee satisfaction in the banking sector of Saudi Arabia. The results show that the impact of incentives provided 
by the bank on job satisfaction, $76.3 \%$ of the sample strongly agreed, while as $3.7 \%$ agreed, $7 \%$ neutral; while as $4.4 \%$ of employees disagreed and $4.8 \%$ strongly disagreed. In regards with the positive impact of promotions and opportunities available at the bank on increasing job satisfaction, $40 \%$ of employees strongly agreed, $7.4 \%$ agreed, $6.7 \%$ neutral, however $21.5 \%$ of the employees disagreed and $24.4 \%$ strongly disagreed. While as $25.2 \%$ of the employees agreed and strongly agreed that the educational resources in the bank could increase job satisfaction, $17.8 \%$ of them were neutral, $12.6 \%$ disagreed and $19.3 \%$ strongly disagreed. 57.8 $\%$ of the employees strongly agreed that disputes among employees in the bank could reduce job satisfaction, while as 19.3\% agreed, 6.7\% neutral, $11.1 \%$ disagree and 5.2\% strongly disagree. Regarding the positive impact of dealing directly with managers and team members on job satisfaction, $56.3 \%$ of employees strongly agreed, $17.8 \%$ agreed, $7.4 \%$ neutral, while as $5.9 \%$ of employees disagreed and $12.6 \%$ strongly disagreed. In regards with the impact of communication difficulty with senior management and different branches at the bank on job satisfaction, $72.6 \%$ of employees strongly agreed, $19.3 \%$ agreed, $1.5 \%$ neutral, however $3.7 \%$ of employees disagreed and $3 \%$ of employees strongly disagreed. Regarding the negative impact of current and future career instability in the bank on job satisfaction, $77.88 \%$ of employees strongly agreed, 16\% agreed, 7\% neutral, however, 5.9\% of employed disagreed. In regards with the positive impact of working hours at the bank on job satisfaction, $32.6 \%$ strongly agreed, $17 \%$ agreed, $10.4 \%$ neutral, $14.1 \%$ disagreed, and $25.9 \%$ of employees strongly disagreed. In regards with impact of policies and regulations to retain the rights of employees on job satisfaction, $34.1 \%$ of employees strongly agreed, $12.6 \%$ agreed, $9.6 \%$ neutral, while as $15.6 \%$ disagreed and $28.1 \%$ strongly disagreed. Regarding the positive impact of the culture of the bank on job satisfaction, $36.3 \%$ of the employees strongly agreed, $17.8 \%$ agreed, $5.9 \%$ neutral, $12.6 \%$ disagreed, and $27.4 \%$ strongly disagreed.

Table - 2; Factors in Employee Satisfaction

\begin{tabular}{|c|c|c|c|c|c|}
\hline Variable influencing the behaviors & $\begin{array}{l}\text { Strongly } \\
\text { Agree }\end{array}$ & Agree & Neutral & $\begin{array}{l}\text { Don't } \\
\text { Agree }\end{array}$ & $\begin{array}{l}\text { Strongly } \\
\text { Disagree }\end{array}$ \\
\hline $\begin{array}{l}\text { 1. Do you think that the incentives provided from Bank } \\
\text { are important for job satisfaction? }\end{array}$ & $76.3 \%$ & $3.7 \%$ & $0.7 \%$ & $4.4 \%$ & $14.8 \%$ \\
\hline $\begin{array}{l}\text { 2. Do you think that promotion opportunities available } \\
\text { at bank could increase job satisfaction? }\end{array}$ & $40 \%$ & $7.4 \%$ & $6.7 \%$ & $21.5 \%$ & $24.4 \%$ \\
\hline $\begin{array}{l}\text { 3. Do you think that all sources of education that Bank } \\
\text { provides to improve productivity increase job } \\
\text { satisfaction? }\end{array}$ & $25.2 \%$ & $25.2 \%$ & $17.8 \%$ & $12.6 \%$ & $19.3 \%$ \\
\hline $\begin{array}{l}\text { 4. Do you think that the conflict between employees at } \\
\text { Bank reduces job satisfaction? }\end{array}$ & $57.8 \%$ & $19.3 \%$ & $6.7 \%$ & $11.1 \%$ & $5.2 \%$ \\
\hline $\begin{array}{l}\text { 5. Do you feel that the direct dealing of your manager } \\
\text { with you and your team members increases your job } \\
\text { satisfaction? }\end{array}$ & $56.3 \%$ & $17.8 \%$ & $7.4 \%$ & $5.9 \%$ & $12.6 \%$ \\
\hline $\begin{array}{l}\text { 6. Do you consider that communication difficulty with } \\
\text { senior management levels and different branches } \\
\text { reduces job satisfaction? }\end{array}$ & $72.6 \%$ & $19.3 \%$ & $1.5 \%$ & $3.7 \%$ & $3 \%$ \\
\hline $\begin{array}{l}\text { 7. Do you feel that job instability in your current } \\
\text { position or regarding your future career at bank } \\
\text { reduces your job satisfaction? }\end{array}$ & $77.8 \%$ & $15.6 \%$ & $0.7 \%$ & $5.9 \%$ & - \\
\hline $\begin{array}{l}\text { 8. Do you think the bank's working hours increase job } \\
\text { satisfaction? }\end{array}$ & $32.6 \%$ & $17 \%$ & $10.4 \%$ & $14.1 \%$ & $25.9 \%$ \\
\hline $\begin{array}{l}\text { 9. Do you think that policies and regulations of bank in } \\
\text { terms of rights of employees at all levels increase job } \\
\text { satisfaction? }\end{array}$ & $34.1 \%$ & $12.6 \%$ & $9.6 \%$ & $15.6 \%$ & $28.1 \%$ \\
\hline $\begin{array}{l}\text { 10. Do you think the culture of bank contributes to } \\
\text { increase job satisfaction? }\end{array}$ & $36.3 \%$ & $17.8 \%$ & $5.9 \%$ & $12.6 \%$ & $27.4 \%$ \\
\hline
\end{tabular}


Table - 3; Factors affecting the level of job satisfaction

\begin{tabular}{|l|c|c|c|c|c|}
\hline Factors Affecting Job Satisfaction & $\begin{array}{c}\text { Strongly } \\
\text { agree }\end{array}$ & Agree & Neutral & Disagree & $\begin{array}{c}\text { Strongly } \\
\text { disagree }\end{array}$ \\
\hline Motivation & $\% 58.15$ & $\% 5.55$ & $\% 3.7$ & $\% 12.95$ & $\% 19.6$ \\
\hline Learning & $\% 25.2$ & $\% 25.2$ & $\% 17.8$ & $\% 12.6$ & $\% 19.3$ \\
\hline Communication & $\% 72.6$ & $\% 19.3$ & $\% 1.5$ & $\% 3.7$ & $\% 3$ \\
\hline Trust & $\% 67.05$ & $\% 16.7$ & $\% 4.05$ & $\% 5.9$ & $\% 12.6$ \\
\hline Conflict & $\% 57.8$ & $\% 19.3$ & $\% 6.7$ & $\% 11.1$ & $\% 5.2$ \\
\hline Organization culture & $\% 36.3$ & $\% 17.8$ & $\% 5.9$ & $\% 12.6$ & $\% 27.4$ \\
\hline Human resources practices and policies & $\% 33.35$ & $\% 14.8$ & $\% 10$ & $\% 14.85$ & $\% 27$ \\
\hline
\end{tabular}

\section{DISCUSSIONS}

There is a large agreement by the sample in the study that the incentives provided by the bank contribute significantly to increase the proportion of job satisfaction, the nature of the work of the branches in the bank encourages employees to increase the sale of products to the customer and the achievement of profits through a system of incentives rewarding for their performance and this is evident through the results of the bank's declared profits annually. Regarding the promotion system at the bank, it was found through the questionnaire that there is a discrepancy between the opinions of the employees. The higher percentage believes that the system of promotions available at the bank has contributed significantly to increase their job satisfaction.

On the other hand, there is a significant percentage that believes that there is no justice in the chances of promotions available at the bank which negatively affected their job satisfaction, due to the lack of career levels in the branches of the bank therefore lack of opportunities for promotion available. It is clear from this discrepancy that there was a defect in the bank's systems related to promotions and improve the status of employees, but Back to the bank systems regarding the promotion system, we find that the bank worked on the development of these systems. A number of career levels have recently been added under the name of a sales consultant in the branches, which will increase the chances of promotion for employees which will significantly increase job satisfaction. We find that the educational resources provided by the bank to employees to help them to increase productivity contribute to improve job satisfaction, according to the majority of respondents. As educational resources contribute significantly to improving staff performance and increasing self-confidence, thereby increasing productivity and obtaining more incentives. And also, in contact with some of the participants in the questionnaire shows that the bank is keen to establish training courses and educational staff periodically to increase the scientific outcome of employees in relation to the products of the bank.

It is clear from the response of the employee to the questionnaire that the conflict between the staff of the bank is a significant factor in reducing job satisfaction where the majority pointed to that. The large number of conflicts in general in the organizations adversely affect the work environment and create an atmosphere of pressure that would affect the employee from the psychological point of view thus reducing the satisfaction of the job. Bank managers also contribute significantly to increasing their employees' job satisfaction. The majority indicated that the manager treated them and the team members well, fairly and with understanding, which reflected their relief in the work environment and thus increased job satisfaction. This is a point for the bank to hire the right person in the right place. It is clear to us through the results of the questionnaire that the vast majority have difficulty in communicating with the levels of senior management and different branches, which led to the reduction of job satisfaction and this indicates that there is a defect in the systems and means of 
communication within the bank. Almost all of the staff involved in the questionnaire were almost agreed that they did not feel stable about their current status and future at the bank, which reduced their sense of job satisfaction.

In general, work in the banking sector in the Kingdom is characterized by instability due to high working pressures and strict regulations and policies. We find that there is a discrepancy in the answers of employees about the work hours and systems and policies of the bank, there are those who find that the bank's working hours and the regulations and policies of the Bank positively affect their job satisfaction, in proportion to their lifestyle. Note that in contrast, a percentage of employees find that the bank's working hours, systems and policies are inappropriate, which negatively affect their job satisfaction, this contrast is due to the different gender of the participants (female - male) and the different social status of the employees in the questionnaire, which leads to different responsibilities. Most respondents agree that the culture of Bank contributes to Increase their job satisfaction.

\section{MAJOR FINDING}

It was found that the independent variables (motivation - learning - communication - trust conflict - organization culture - human resources practices and policies) affect some of them positively and others negatively on the level of job satisfaction of employees in the bank, we found that:

1- It has been shown that the incentive system at the bank is good and positively affects the contribution of employee satisfaction.

2- While there was variation regarding the promotion system in the bank and its impact on job satisfaction due to a defect in the functional levels in the branches, and the bank in the recent period is working on the development of promotion systems.

3- As for the independent variable of learning, we find that it has a positive effect in increasing the job satisfaction of the staff of the bank due to the availability of different sources of education provided by the bank.

4- As far as communication is concerned, staff have difficulty communicating with senior management and various branches, which has greatly reduced job satisfaction.

5- The trust factor in the bank was measured based on job security relative to their current and future position within the bank, it was found that the employees did not feel very confident about their future in the bank, which negatively affected the job satisfaction.

6- For the independent variable of conflict, the results indicate that it has a significant negative impact on the job satisfaction of the employees of the bank.

7- The variable organizational culture positively affects the level of job satisfaction of employees in the bank.

8- For the independent variable, human resources policies and practices in relation to the number of work hours in the bank and the regulations and procedures that safeguard the rights of employees there is a significant positive impact on the level of job satisfaction.

\section{RECOMMENDATION}

- The researchers recommend that banks should improve the promotion system, so as to increase employee's satisfaction and achieve the objectives of the bank and increase profits.

- Develop and improve staff assessment systems and encourage employees to compete honestly, so as to reduce disputes within the bank and increase job satisfaction.

- Improve communication procedures with senior management levels and other branches, diversify the techniques and systems used. 
- It is also recommended that bank management should improve laws and regulations related to retaining the rights of employees, so as to increase their sense of job security and their future in the bank, which reflects positively on their performance and productivity at the bank.

- The researchers also recommend that bank management should increase all methods and procedures required to achieve a comfortable working environment for the employees, for example opening a nursery for the children of female employees.

\section{CONCLUSION}

Recently, organizations have been increasingly interested in trying to measure employee satisfaction and making efforts to develop, improve and increase the ratio of job satisfaction in the organization. Where job satisfaction has been shown to increase productivity and help achieve the organization's goals, as well as to increase employee loyalty, thereby increasing customer satisfaction and its impact on organizations' profits. In this research we tried to identify several factors and measure their impact on job satisfaction to facilitate the bank's task in achieving it. A questionnaire was distributed among employees of the Bank to determine their level of job satisfaction and their opinions on what factors positively affect and, conversely, what factors are negatively impacting.

We have found that the factors that have a positive impact on the job satisfaction of bank employees are the learning, motivation, the human resources policies and practices, and the organizational culture of the bank in general, which are good points for the bank.

In contrast, we found that there are some important factors in increasing job satisfaction which the Bank has not yet developed and improved. These factors are communication and the conflict factor between the employees and Trust factor has had a negative impact on the job satisfaction from the point of view of employees in the bank.

One of the most important recommendations that we recommend to the bank to try to develop and improve its weaknesses in terms of employee satisfaction of employees to raise the level of loyalty of employees of the bank, which contributes to increase customer satisfaction about the bank.

Also reduce the turnover of good employees and thus benefit from their expertise and their contribution to increase the efficiency of the operations of the bank and reduce the percentage of absenteeism of employees by trying to build a comfortable working environment and stress free to encourage employees to do their job to the fullest and increase productivity. 


\section{References}

Alromaihi, M. A., Alshomaly, Z. A., and George, S. (2017). Job satisfaction and employee performance: A theoretical review of the relationship between the two variables. International Journal of Advanced Research in Management and Social Sciences, 6(1), pp. 1-20.

Kaur, A. (2013). Maslow's need hierarchy theory: Applications and criticisms. Global Journal of Management and Business Studies, 3(10), pp. 1061-1064.

Schein.E. (1984). Coming to a new awareness of organizational culture. Sloan Management Review, 25(2), pp. 316.

Belbin, M.R., (2011) Management teams: Why they succeed or fail. Human Resource Management International Digest, 19(3).

Brewster, C. and Mayrhofer, W. eds., (2012) Handbook of research on comparative human resource management. Edward Elgar Publishing.

Daley, D.M., (2012) Strategic human resource management. Public Personnel Management, pp.120-125.

De Vos, A., De Hauw, S. and Van der Heijden, B.I., (2011) Competency development and career success: The mediating role of employability. Journal of Vocational Behavior, 79(2), pp.438-447.

Egan, G., (2013) The skilled helper: A problem-management and opportunity-development approach to helping. Cengage Learning.

Ely, R.J., Ibarra, H. and Kolb, D.M., (2011) Taking gender into account: Theory and design for women's leadership development programs. Academy of Management Learning \& Education, 10(3), pp.474-493.

Gurdjian, P., Halbeisen, T. and Lane, K., (2014) Why leadership-development programs fail. McKinsey Quarterly, 1, pp.121-126.

Hoekstra, H.A., (2011) A career roles model of career development. Journal of Vocational Behavior, 78(2), pp.159173.

Ismajli, N., Krasniqi, I. and Qosja, E., (2015) Career development and advancement of human resources-how they influence the performance qualities of local government administration.

Johnson, M., Cowin, L.S., Wilson, I. and Young, H., (2012) Professional identity and nursing: contemporary theoretical developments and future research challenges. International nursing review, 59(4), pp.562-569.

Karim, M.R., Huda, K.N. and Khan, R.S., (2012) Significance of training and post training evaluation for employee effectiveness: An empirical study on Sainsbury's Supermarket Ltd, UK. International Journal of Business and Management, 7(18), p.141.

Khan, R.A.G., Khan, F.A. and Khan, M.A., (2011) Impact of training and development on organizational performance. Global Journal of Management and Business Research, 11(7).

Kraimer, M.L., Seibert, S.E., Wayne, S.J., Liden, R.C. and Bravo, J., (2011) Antecedents and outcomes of organizational support for development: the critical role of career opportunities. Journal of Applied Psychology, 96(3), p.485.

Latif, F.K., (2012) An integrated model of training effectiveness and satisfaction with employee development interventions. Industrial and Commercial Training, 44(4), pp.211-222.

Lussier, R., (2011)Management fundamentals: Concepts, applications, skill development. Cengage Learning.

Sadri, G. and Bowen, C.R., (2011) Meeting employee requirements: Maslow's hierarchy of needs is still a reliable guide to motivating staff. Industrial engineer, 43(10), pp.44-49.

Şahin, F., (2012) The mediating effect of leader-member exchange on the relationship between Theory X and Y management styles and affective commitment: A multilevel analysis. Journal of Management \& Organization, 18(02), pp.159-174.

Sharf, R.S., (2016) Applying career development theory to counseling. Cengage Learning. 


\section{Gender}

\section{APPENDIX (QUESTIONNAIRE)}

Male

Female

\section{Age}

From 20 to 25

From 25 to 35

More than 35

\section{Level of education}

\section{Secondary}

Diploma

Bachelor

\section{Master or PhD}

\section{Social status}

\section{Single}

Married

Divorced or widow/widower

\section{Salary average}

Less than 5000

From 5000 to 10,000

More than 10,000

\begin{tabular}{|c|c|c|c|c|c|}
\hline Variables & $\begin{array}{l}\text { Strongly } \\
\text { Agree }\end{array}$ & Agree & Neutral & Disagree & $\begin{array}{l}\text { Strongly } \\
\text { Disagree }\end{array}$ \\
\hline \multicolumn{6}{|l|}{$\begin{array}{l}\text { Do you think that the incentives provided from Bank are } \\
\text { important for job satisfaction? }\end{array}$} \\
\hline \multicolumn{6}{|l|}{$\begin{array}{l}\text { Do you think that promotion opportunities available at } \\
\text { bank could increase job satisfaction? }\end{array}$} \\
\hline \multicolumn{6}{|l|}{$\begin{array}{l}\text { Do you think that all sources of education that Bank } \\
\text { provides to improve productivity increase job } \\
\text { satisfaction? }\end{array}$} \\
\hline \multicolumn{6}{|l|}{$\begin{array}{l}\text { Do you think that the dispute Which exists between } \\
\text { employees at Bank reduces job satisfaction? }\end{array}$} \\
\hline \multicolumn{6}{|l|}{$\begin{array}{l}\text { Do you feel that the direct dealing of your manager with } \\
\text { you and your team members increases your job } \\
\text { satisfaction? }\end{array}$} \\
\hline \multicolumn{6}{|l|}{$\begin{array}{l}\text { Do you consider that communication difficulty with } \\
\text { senior management levels and different branches } \\
\text { reduces your job satisfaction? }\end{array}$} \\
\hline \multicolumn{6}{|l|}{$\begin{array}{l}\text { Do you feel that job instability in your current position } \\
\text { or regarding your future career at bank reduces your } \\
\text { job satisfaction? }\end{array}$} \\
\hline \multicolumn{6}{|l|}{$\begin{array}{l}\text { Do you think the bank's working hours increase job } \\
\text { satisfaction? }\end{array}$} \\
\hline \multicolumn{6}{|l|}{$\begin{array}{l}\text { Do you think that policies and regulations of bank in } \\
\text { terms of rights of employees at all levels increase job } \\
\text { satisfaction? }\end{array}$} \\
\hline $\begin{array}{l}\text { Do you think the culture of bank contributes to increase } \\
\text { job satisfaction? }\end{array}$ & & & & & \\
\hline
\end{tabular}

